\title{
Severe leptospirosis in a Dutch traveller returning from the Dominican Republic, October 2011
}

M S Arcilla ${ }^{1}$, P J Wismans ${ }^{1}$, Y van Beek-Nieuwland ${ }^{1}$, P J van Genderen (p.van.genderen@havenziekenhuis.nl) ${ }^{1}$

1. Institute for Tropical Diseases, Department of Internal Medicine, Havenziekenhuis, Rotterdam, the Netherlands

Arcilla MS, Wismans PJ, van Beek-Nieuwland Y, van Genderen PJ. Severe leptospirosis in a Dutch traveller returning from the Dominican Republic, October 2011. Euro Surveill. 2012;17(13): pii=20134. Available online: http://www.eurosurveillance.org/ViewArticle.aspx?Articleld=20134

In October 2011, a case of leptospirosis was identified in a Dutch traveller returning from the Dominican Republic to the Netherlands. The 51-year-old man had aspired muddy water in the Chavón river on 29 September. Twenty days later he presented with fever, nausea, vomiting, diarrhoea, arthralgia, headache, conjunctival suffusion and icterus. Leptospira serovar Icterohaemorrhagiae or Australis infection was confirmed ten days later by laboratory testing.

We report on a patient diagnosed with leptospirosis following travel to the Dominican Republic. Only a few cases of leptospirosis have been described among travellers to the Dominican Republic [1]. This case serves as a reminder for physicians to consider leptospirosis in the differential diagnosis of febrile patients returning from the Dominican Republic.

\section{Case report}

At the end of September 2011, a 51-year-old Dutch male spent 14 days at a tourist resort in Punta Cana, Dominican Republic. During his stay he made several excursions, among which one was a swimming excursion to the Chavón river near the village Altos de Chavón. While swinging from a vine, he fell in the river. His travel companions covered his body and face with mud from the river bank, which caused the patient to aspire muddy water. Twenty days after this incident, when back in the Netherlands, he presented with fever, nausea, vomiting, diarrhoea, arthralgia and headache at the outpatient department of the Havenziekenhuis in Rotterdam. On physical examination conjunctival suffusion and icterus was noted. Laboratory results showed raised C-reactive protein (280 mg/L, norm: 0-10 mg/L),

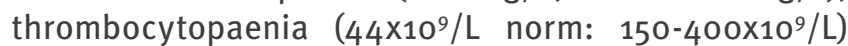
and total bilirubin $(104 \mu \mathrm{mol} / \mathrm{L}$, norm: 0-17 $\mu \mathrm{mol} / \mathrm{L})$ without a marked increase in liver transaminases, and signs of renal dysfunction (creatinine $268 \mu \mathrm{mol} / \mathrm{L}$, norm: 65-115 $\mu \mathrm{mol} / \mathrm{L}$ ). After admission, the clinical condition of the patient deteriorated with hypotension, progressive kidney failure and anuria for which he was admitted to the Intensive Care Unit. Because there had been typical exposure to mud, twenty days prior to the clinical manifestations, the working diagnosis was septicaemia due to leptospirosis.

The diagnosis was confirmed by the demonstration of specific agglutinating antibodies against Leptospira spp in a microscopic agglutination test (MAT), titer 1:320, and specific immunoglobulin $M$ (IgM) antibodies (ELISA > 1:160) in a second sample taken 10 days after presentation. Interestingly, even though serology was negative in the serum sample taken on admission, a real-time PCR was positive $[2,3]$. The causative serovar was identified by the MAT as probably belonging either to the Leptospira serovar Icterohaemorrhagiae or Australis [4]. Other potential diseases such as malaria and dengue, were excluded. Blood cultures taken on admission remained negative.

He was treated with ceftriaxone intravenously and doxycycline orally. The patient's condition improved following intensive fluid resuscitation and infusion of vasopressors. His renal function had recovered completely after seven days and after 10 days, the patient left the hospital.

His fellow travellers remained asymptomatic throughout this period.

\section{Background}

Leptospirosis is a worldwide zoonotic infection with a much greater incidence in tropical regions $[5,6]$. An increasing number of imported cases of leptospirosis following international travel are being published [7]. High risk areas include India, Sri-Lanka, Thailand, Vietnam, Malaysia, China, Seychelles, the Caribbean, Brazil and the Pacific Islands. Leptospirosis is now considered an emerging disease in travellers [8]. Human infection results from exposure to infected urine from carrier mammals, either directly or via contamination of soil or water. Leptospirosis in travellers is usually associated with recreational activities that involve contact with freshwater, soil and animals such as jungle trekking and kayaking [9]. 


\section{Conclusions}

Statistics published by the Epidemiology Department of the Dominican Ministry of Public Health show that from January until mid-March 2012 there were 211 suspected cases of leptospirosis [10]. In 2011, there were a total of 891 suspected cases of leptospirosis in the Dominican Republic, a clear decrease compared with 2010 when there were 1,270 suspected cases [10]. As outbreaks often occur following natural disasters such as earthquakes, weather conditions as rainstorms and ensuing floods could have an impact on the incidence of leptospirosis in the Dominican Republic [11].

Physicians taking care of travellers returning ill with fever should consider leptospirosis a differential diagnosis in those who have travelled to areas where Leptospira spp are endemic and those who participated in high-risk activities. Given the potentially fatal course of severe leptospirosis, pre-emptive antibiotic treatment for leptospirosis should be considered without delay in febrile travellers returning from endemic regions, who have been exposed to freshwater and soil or have had skin contact with animals [12-15]. Travellers who plan to engage in water activities should be advised about preventive measures such as wearing protective clothing and shoes, and to cover up abrasions.

\section{Acknowledgments}

We would like to thank Mr. H. van der Linden from the National Leptospirosis Reference Laboratory of the Royal Tropical Institute Biomedical Research, Amsterdam, the Netherlands for providing information concerning the diagnostic tests.

\section{References}

1. Grobusch MP, Bollmann R, Schönberg A, Slevogt H, Garcia V, Teichmann D et al. Leptospirosis in Travelers Returning from the Dominican Republic. J Travel Med. 2003;10(1):55-8.

2. Ahmed A, Engelberts MFM, Boer KR, Ahmed N, Hartskeerl RA. Development and Validation of a Real-Time PCR for Detection of Pathogenic Leptospira Species in Clinical Materials. PLoS. One 2009;4(9):e7093. doi:10.1371/journal.pone.0007093

3. Faucher JF, Hoen B, Estavoyer JM. The management of leptospirosis. Expert Opin Pharmacother. 2004;5(4):819-27.

4. Levett PN. Usefulness of serologic analysis as a predictor of the infecting serovar in patients with severe leptospirosis. Clin Infect Dis, 2003;36(4):447-52.

5. Levett PN. Leptospirosis. Clin Microbiol Rev. 2001 Apr;14(2):296-326.

6. Bharti AR, Nally JE, Ricaldi JN, Matthias MA, Diaz MM, Lovett MA et al. Leptospirosis: a zoonotic disease of global importance. Lancet Infect Dis. 2003;3(12):757-71

7. Pavli A, Maltezou HC. Travel-acquired leptospirosis. J Travel Med. 2008;15:447-53

8. Lau C, Smythe L, Weinstein P. Leptospirosis: an emerging disease in travellers. Travel Med Infect Dis. 2010;8(1):33-9

9. Narita M, Fujitani S, Haake DA, Paterson DL. Leptospirosis after recreational exposure to water in the Yaeyama islands, Japan. Am J Trop Med Hyg. 2005;73(4):652-6.

10. Ministry of Public Health, Epidemiology Department [Internet]. Dominican Republic. Statistics. Available from: www. sespasdigepi.gob.do

11. World Health Organization: Weekly epidemiological record. Leptospirosis: an emerging public health problem. 4 Februar 2011. No 6, 2011, 86, 45-52.
12. Panaphut $T$, Domrongkitchaiporn $S$, Vibhagool A, Thinkamrop B, Susaengrat W. Ceftriaxone compared with sodium penicillin $\mathrm{g}$ for treatment of severe leptospirosis. Clin Infe Dis. 2003;36(12):1507-13.

13. Suputtamongkol Y, Niwattayakul K, Suttinont C, Losuwanaluk $\mathrm{K}$, Limpaiboon R, Chierakul W et al. An open, randomized, controlled trial of penicillin, doxycycline, and cefotaxime for patients with severe leptospirosis. Clin Infect Dis. 2004; 39:1417-24.

14. Griffith ME, Hospenthal DR, Murray CK. Antimicrobial therapy of leptospirosis. Curr Opin Infect Dis. 2006;19(6):533-7.

15. Vinetz, JM. A mountain out of a molehill: Do we treat acute leptospirosis, and if so, with what? Comment on Clin Infect Dis. 2003;36(12):1507-13 